\title{
The Role Of Intangible Assets And Other Accounting Issues In A Corporate Disaster
}

Rae Weston, (E-mail: rweston@laurel.ocs.mq.edu.au), Macquarie Graduate School of Management, Australia

\begin{abstract}
In this paper we investigate the role of intangible assets, slotting costs and the failure to provide for legal contingencies in the problems that beset Burns Philp., an Australian blue chip company in 1997. We also move the combination of problems to a 2005 perspective and ask if in the light of recent developments in the accounting for intangible assets and contingencies ( IAS 38) directors would be in a better position to inform shareholders adequately or not.
\end{abstract}

\section{INTRODUCTION}<smiles>[CH]1CCCCC1</smiles>

n September 1997 the Australian blue chip company, Burns Philp announced a \$A700 writedown of assets. The size and the suddenness of the writedown led to an investigation by the Australian Securities and Investment Commission (1998) which while it did not suggest that the directors of the company should be faced with legal proceedings, drew attention to five matters of public interest: first, that directors are responsible to ensure that the board functions effectively; second that directors are responsible to ensure that they are appropriately informed about business performance; third, that directors must question and evaluate key features of intangible asset valuation reports ;fourth, that directors are responsible for ensuring that shareholders are appropriately informed; and, fifth, that auditors must question and evaluate material intangible asset valuations.

In this paper we investigate the role of intangible assets, slotting costs and the failure to provide for legal contingencies in the problems that beset Burns Philp. We also move the combination of problems to a 2005 perspective and ask if in the light of recent developments in the accounting for intangible assets and contingencies ( IAS 38) directors would be in a better position to inform shareholders adequately or not.

'We focus on three particular issues; the significance of industry-specific intangible asset valuations and their difference from general principles; the importance of the classification of slotting costs as assets rather than expenses and the failure to recognise a legal contingency which added materially to the losses of the company during the same time period. Burns Philp was one of Australia's oldest blue chip companies. It began business in 1876 operating as an island trader, owning a shipping line and copra plantations as well as owning, maintaining and servicing stores in the South Pacific. Later Burns Philp diversified into hardware and then into the food and yeast business. When it disposed of its hardware business in 1994, it used the funds for further growth in the food sector, embarking on an aggressive herbs and spices business acquisition program, which is detailed in Table 1.

Table 1

\begin{tabular}{ll}
\hline Year & Acquisition \\
1988 & Specialty Brands Inc \\
1990 & T J Lipton Co. \\
1989 & British Pepper \& Spice \\
1990 & Euroma (Netherlands) \\
1993 & Ostmann (German company) \\
1994 & Tone \\
\hline
\end{tabular}


As can be seen from this table, Burns Philp began its acquisition of herbs and spices businesses in 1988. The rationale for the company's strategy in the market as explained by the chairman, Alan McGregor (at the November 1997 AGM) was "it was a niche market, fragmented and open to rationalisation opportunities. As a consequence the opportunities presented were complementary to Burns Philp's proven and successful yeast strategy. Furthermore in many instances, it enabled the company to be a single source supplier to many customers for their food ingredient products."

The architects of the strategy were Andrew Turnbull, Ian Clack and John Cowling. Andrew Turnbull was appointed to the Board in 1983, was CEO from 1984 to 1994 and appointed chairman in 1994. Ian Clack had been with Burns Philp since 1961, was general manager of the food operations from 1983 and was instrumental in the global expansion of the food ingredients businesses. He was appointed chairman in 1994. John Cowling, a chartered accountant, joined the company in 1979 and after holding positions as General Manager, Finance and General Manager Asia Pacific, was appointed President of the yeast/bakery division in 1996.

By 1994 the company had acquired a range of herbs and spice businesses with successful trade names and had begun a consolidation/rationalisation program in North America with the intent of achieving economies of scale. With the purchase of Tone's North American business and the German company Ostmann in that year Burns Philp became the world's second largest herbs and spices business.

\section{THE ROLE OF INTANGIBLES}

Throughout the acquisition program the accounting treatment used enabled the costs of purchasing trade names and goodwill to be treated as the acquisition of intangible assets. Bukh, Chemnitz and Thisgaard (2003, at p.5) described intangibles as:

sources of probable future economic profits lacking physical substance which are controlled or at least influenced by a company as a result of previous events and transactions (self-production, purchase or any other type of acquisition) and may or may not be sold separately from other corporate assets

For each of its acquisitions Burns Philp raised significant restructuring and rationalisation provisions which were balanced by increasing the value of intangible assets which included the trade names, technological assets and goodwill. The difference between the at cost valuation of the tradenames and the valuations provided for by Valuation Research Corporation (VRC) a US-based valuer of company tradenames is shown in Table 2 below.

Table 2

Valuation Of Tradenames \$A M (Years To June 30)

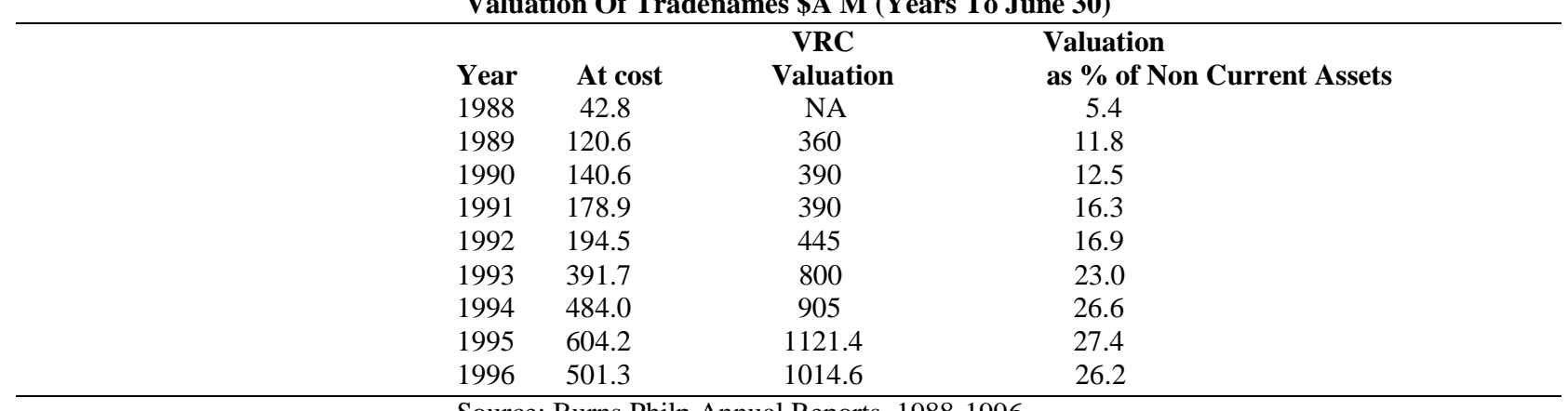

Source: Burns Philp Annual Reports, 1988-1996

Their increasing importance to the company is represented by the last line of the table which reports the tradename valuations as a \%age of non-current assets. 
VRC and Barings who were engaged to review and validate VRC's methodology, both used the "relief from royalty " approach which calculates an amount of royalty as if another company owns the tradename. This amount is a percentage of revenue derived from the tradename products which depended on several factors such as "historic and projected revenues and operating results for the various reporting groups and products of the company" and in using these VRC "accepted the company's information on these "as an accurate representation of the actual results to date and as reasonable estimates of future sales and financial performance".

The ASIC report due attention (at p.33) to the problems arising from the directors failure to allow for changes in the following assumption clearly stated by VRC in its valuation report:

This value definition assumes the appraised assets continue in their current use as part of the ongoing business. It also assumes that earnings from operations are adequate to justify the investment in the appraised assets at the concluded fair market value.

ASIC suggested as an example that the British Pepper \& Spice results as shown in Table 3 below, did not justify the above assumption.

Table 3

British Pepper \& Spice

(Acquired 1993, Sold May 1998)

\begin{tabular}{lccc}
\hline \$Am & 1994 & 1995 & 1996 \\
EBIT & 0.07 & $(0.7)$ & $(0.6)$ \\
Contribution to group profit & & & \\
(loss) after interest \& tax & $(0.8)$ & $(1.9)$ & $(3.2)$ \\
Tradename Valuation by VRC & 1.3 & 1.9 & 1.5 \\
\hline
\end{tabular}

Source: ASIC Report p. 3

There was no evidence that the directors had ever made reasonableness checks of these assumptions. Prudence on the part of the directors might have led to the valuation figures being at least reconsidered from 1993 on when they become a very significant part of non-current assets.

\section{THE ROLE OF SLOTTING FEES}

Slotting fees were the payments made to supermarkets to obtain the right to shelf space and in many cases to ensure that the supermarkets would not carry competitors' products. Slotting fees were up-front contractual payments in contracts made for three or four years. Slotting fees were used as a competitive strategy, especially between McCormick's and Burns Philp in the US market as McCormicks defended their business. The slotting payment for the initial year of the contract was charged against profit in that year, but the amount relating to later years was capitalised as prepaid slotting fees.

The expectation under which Australian accounting rules allowed expenses to be capitalised and carried forward was that it would reasonable that sufficient revenue would be earned in later years to recover the expenditure. While the effect of the capitalisation was to increase assets and to reduce expenses, improving both the balance sheet and the profit and loss statement, the company was unable to make profits from the spice contracts. The increasing scale of the slotting fees paid is shown in Table 3 below. From a comparatively minor amount of $\$ 3.9 \mathrm{~m}$ in 1992 total slotting fees reached a peak of $\$ 185.8 \mathrm{~m}$ in 1995 . 
Table 3: Burns Philp-Capitalised Slotting Fees 1992-96

\begin{tabular}{|l|c|c|c|c|c|}
\hline Capitalised slotting fees & 1992 & 1993 & 1994 & 1995 & 1996 \\
\hline Current assets in \$m & - & 23.9 & 30.1 & 54.2 & 35.3 \\
\hline Non-current assets in \$m & 3.9 & 57.3 & 74.5 & 131.7 & 84.0 \\
\hline Total fees in \$m & 3.9 & 81.2 & 104.6 & 185.9 & 119.3 \\
\hline
\end{tabular}

Source: Burns Philp Annual Report 1992-97

Once again prudence would have suggested revisiting the treatment of slotting fees in this manner, again as with the earlier expenses from 1993 onwards.

\section{LEGAL CONTINGENCIES}

While the focus of the company was unquestionably on the spice business, the company was involved in several other businesses, including among them Burns Philp Trustee Company Ltd. This company had become trustee for the Estate Mortgage trusts in 1983.These trusts had serious liquidity problems and in the second half of 1990 borrowers and lenders commenced legal action against the company and in October 1990 Burns Philp Trustee Company Ltd was put into liquidation. A year later the trustees in the liquidation sought compensation for breaches of trust from both Burns Philp Trustee Company Ltd and from Burns Philp \& Company Ltd. Burns Philp made no provision at all for the contingent liability represented by the lawsuit. The author of this paper was able to ask the then CEO, Andrew Turnbull why they had not done so. His answer was that the Company had legal advice that it would not be liable and accordingly had made no provision in the accounts at all. An appropriate amount could have been reasonably ascertained as Tyndall who made the claim had made several offers to settle with Burns Philp.

In the event the Company was found liable and substantial funds were required for the settlement in 1997 , with $\$ 90 \mathrm{~m}$ in cash and \$26 m in convertible notes eventually provided for in 1996 and paid in July 1997 . The timing of this caused difficulties for the parent company as it had to renegotiate the covenant for its debt to equity

\section{SUMMARY}

The information provided above makes it clear that the directors of Burns Philp were extremely optimistic about their herbs and spices business and took much too long to take a more realistic view of their prospects of making profits from that business. The signs seemed to be clear from 1993 onward that the company needed to be very certain that profits would ensue from this business.

\section{A 2005 PERSPECTIVE}

There is now an International Accounting Standard, IAS 38, which deals with accounting for intangibles. IAS 38.8 lists the three critical attributes of an intangible asset as identifiability; control, that is, power to obtain benefits from the asset; and future economic benefits, such as revenues or reduced future costs. Allowing that the tradenames and slotting fees fall within the IAS 38 definition of intangible assets, the directors' assumptions about control and future economic benefits would still be key to their continued valuation in the balance sheet.

The difficulties that beset the company as a consequence of an optimistic over-reliance on future economic benefits would not it seems have been reduced by the application of IAS 38 .

As with the treatment of potential legal liability, it appears that the directors' ill-founded optimism would not have had any different result had it occurred more recently. While our discussion has focused on the various accounting issues raised by the Burns Philp case there is a second interpretation of the above mentioned circumstances which is that the directors did not seem to have adequate information about the business of herbs and spices either when they commenced it, or as its development attained crucial significance for the company.

Recourse to the Corporations Act 2001 s 180(2) which requires directors to acquire a basic understanding of the business of the company and to be familiar with the fundamentals of the company's business does not give any 
greater comfort although the duty of care requirement that directors should maintain familiarity with the financial status of the company by a regular review of financial accounts would hopefully have led the directors to revisit the position of the valuation of tradenames and slotting fees in 1993 and in subsequent years.

\section{CONCLUSION}

In this paper we have investigated the role of intangible assets, slotting costs and the failure to provide for legal contingencies in the problems that beset Burns Philp. We also moved the combination of problems to a 2004 perspective and asked if in the light of recent developments in the accounting for intangible assets and contingencies (IAS 38) directors would be in a better position to inform shareholders adequately or not.

We focused on three particular issues; the significance of industry-specific intangible asset valuations and their difference from general principles; the importance of the classification of slotting costs as assets rather than expenses and the failure to recognise a legal contingency which added materially to the losses of the company during the same time period.

We conclude that while the industry-specific nature of some intangible assets still makes their correct valuation problematical; that the recognition of slotting costs as costs and not assets should alert a questioning board to the problems of the business; and that the failure to recognise a legal contingency might still be regarded as a judgement call by management and directors although it can be shown not to be prudent to do so.

It does appear that the ceaseless optimism of directors is still a key ingredient in corporate disasters and that neither accounting conventions nor corporate law provisions seem able to temper this to a more cautious stance.

\section{REFERENCES}

1. Australian Securities and Investments Commission (1998) Report of the Investigation into Burns Philp \& Company Ltd December.

2. Burns Philp, Annual Reports, various years.

3. Bukh, P. N., M.L. Chemnitz and L. Thisgaard (2003) Defining a research agenda regarding intangibles $E^{*} K N O W-N E T$, October.

4. Holland, John and Ulf Johanson(2003) Value-relevant information on corporate intangibles-creation, use and barriers in capital markets-between a rock and a hard place Journal of Intellectual Capital vol 4 No 4. 


\section{NOTES}

